University of Nebraska - Lincoln

DigitalCommons@University of Nebraska - Lincoln

\title{
A Lidar-Derived Evaluation Of Watershed-Scale Large Woody Debris Sources And Recruitment Mechanisms: Coastal Maine, USA
}

\author{
A. Kasprak \\ Dartmouth College, akasprak@aggiemail.usu.edu \\ F. J. Magilligan \\ Dartmouth College, magilligan@dartmouth.edu \\ K. H. Nislow \\ USDA Northern Research Station, knislow@fs.fed.us \\ N. P. Snyder \\ Boston College, noah.snyder@bc.edu
}

Follow this and additional works at: https://digitalcommons.unl.edu/usdaarsfacpub

Kasprak, A.; Magilligan, F. J.; Nislow, K. H.; and Snyder, N. P., "A Lidar-Derived Evaluation Of Watershed-Scale Large Woody Debris Sources And Recruitment Mechanisms: Coastal Maine, USA" (2011). Publications from USDA-ARS / UNL Faculty. 1104.

https://digitalcommons.unl.edu/usdaarsfacpub/1104

This Article is brought to you for free and open access by the U.S. Department of Agriculture: Agricultural Research Service, Lincoln, Nebraska at DigitalCommons@University of Nebraska - Lincoln. It has been accepted for inclusion in Publications from USDA-ARS / UNL Faculty by an authorized administrator of DigitalCommons@University of Nebraska - Lincoln. 


\title{
A LIDAR-DERIVED EVALUATION OF WATERSHED-SCALE LARGE WOODY DEBRIS SOURCES AND RECRUITMENT MECHANISMS: COASTAL MAINE, USA
}

\author{
A. KASPRAK, ${ }^{\mathrm{a} *}$ F. J. MAGILLIGAN, ${ }^{\mathrm{b}}$ K. H. NISLOW ${ }^{\mathrm{c}}$ and N. P. SNYDER ${ }^{\mathrm{d}}$ \\ a Department of Earth Sciences, Dartmouth College, Hanover, New Hampshire 03755, USA \\ ${ }^{\mathrm{b}}$ Department of Geography, Dartmouth College, Hanover, New Hampshire 03755, USA \\ ${ }^{\mathrm{c}}$ USDA Northern Research Station, Amherst, Massachusetts 01103, USA \\ ${ }^{\mathrm{d}}$ Department of Earth and Environmental Sciences, Boston College, Chestnut Hill, Massachusetts 02467, USA
}

\begin{abstract}
In-channel large woody debris (LWD) promotes quality aquatic habitat through sediment sorting, pool scouring and in-stream nutrient retention and transport. LWD recruitment occurs by numerous ecological and geomorphic mechanisms including channel migration, mass wasting and natural tree fall, yet LWD sourcing on the watershed scale remains poorly constrained. We developed a rapid and spatially extensive method for using light detection and ranging data to do the following: (i) estimate tree height and recruitable tree abundance throughout a watershed; (ii) determine the likelihood for the stream to recruit channel-spanning trees at reach scales and assess whether mass wasting or channel migration is a dominant recruitment mechanism; and (iii) understand the contemporary and future distribution of LWD at a watershed scale. We utilized this method on the 78-km-long Narraguagus River in coastal Maine and found that potential channel-spanning LWD composes approximately $6 \%$ of the valley area over the course of the river and is concentrated in spatially discrete reaches along the stream, with $5 \mathrm{~km}$ of the river valley accounting for $50 \%$ of the total potential LWD found in the system. We also determined that $83 \%$ of all potential LWD is located on valley sides, as opposed to $17 \%$ on floodplain and terrace surfaces. Approximately $3 \%$ of channel-spanning vegetation along the river is located within one channel width of the stream. By examining topographic and morphologic variables (valley width, channel sinuosity, valleyside slope) over the length of the stream, we evaluated the dominant recruitment processes along the river and often found a spatial disconnect between the location of potential channel-spanning LWD and recruitment mechanisms, which likely explains the low levels of LWD currently found in the system. This rapid method for identification of LWD sources is extendable to other basins and may prove valuable in locating future restoration projects aimed at increasing habitat quality through wood additions. Copyright (C) 2011 John Wiley \& Sons, Ltd.
\end{abstract}

KEY WORDS: large woody debris; lidar; river restoration; habitat

Received 5 November 2010; Revised 16 March 2011; Accepted 30 March 2011

\section{INTRODUCTION}

The presence of large woody debris (LWD) in streams is associated with an array of positive ecological impacts (Gurnell et al., 2002). Studies have shown wood to be an important mechanism in promoting stream habitat heterogeneity through sediment storage and sorting (Beschta, 1979; Assani and Petit, 1995; Thompson, 1995), pool formation (Montgomery et al., 1995; Abbe and Montgomery, 1996) and in-stream nutrient transport (Bilby, 2003). The influence of in-channel wood on these physical processes can translate to critical habitat for numerous organisms, such as salmonid fishes (Fausch and Northcote, 1991; Sundbaum and Näslund, 1997). Owing to the importance of LWD as a habitat-forming agent, a large literature has developed concerning the ecological role of instream wood (Gregory et al., 2003) and the physical

*Correspondence to: A. Kasprak, Department of Watershed Sciences, Utah State University, Logan, Utah 84322, USA.

E-mail: akasprak@aggiemail.usu.edu mechanisms that promote recruitment of wood from riparian and hillslope forests (Benda et al., 2003). The view of wood in streams today lies in contrast to past perceptions that streams needed to be freed from obstruction (Erskine and Webb, 2003), to the degree that projects are underway to add wood and/or artificial wood structures to rivers in hopes of fostering the return of high-quality fluvial habitat (Cederholm et al., 1997; Floyd et al., 2009; Johnson, 2009).

The delivery of wood to streams has been studied extensively, with particular regard to the Pacific Northwest, and has been shown to occur by several processes (Benda et al., 2003). Trees can be sourced to streams through hillslope failure (Swanson and Lienkaemper, 1978; May and Gresswell, 2003a), wind throw (Lienkaemper and Swanson, 1987; Hairston-Strang and Adams, 1998) and bank undercutting (Swanson and Lienkaemper, 1978; Webb and Erskine, 2003). Numerous processes can accelerate wood recruitment, such as fire and insect outbreaks (Bragg, 2000), which result in largescale tree mortality. The distance of trees from the channel has been shown to be an important factor in LWD delivery 
(McDade et al., 1990), with those trees closer to streams being preferentially recruited. The distribution of wood in streams has been further shown to reflect a balance between the amount of wood recruited and the ability of the stream to transport it and form wood jams (Wohl and Jaeger, 2008; Wohl et al., 2010). This longitudinal variation in wood distribution can be due to controlling factors such as channel gradient, with wood being redistributed from higher to lower energy reaches (Magilligan et al., 2008; Fisher et al., 2010).

Maintaining the natural state of streams and restoring previously disturbed rivers are emerging as important goals of fluvial geomorphology. Yet recent work has indicated that the rate at which such projects are proceeding outpaces our scientific knowledge of fluvial and riparian dynamics (Kondolf, 1995; Wohl et al., 1995; Bernhardt et al., 2005; Snyder et al., 2009; Wilkins and Snyder, 2010). Although the management of such dynamics at the watershed scale may be a beneficial approach for habitat restoration (May and Gresswell, 2003a), such a basin-scale understanding in the case of LWD sources and recruitment has not been achieved (Seo et al., 2010) despite the increasing popularity of LWD as a restoration tool. Watershed-scale analyses, although possible, may be complicated by the time-intensive methods required (Marcus et al., 2002; Fremier et al., 2010) or the complex nature of attributes such as floodplain connectivity or hillslope characteristics, which can influence both LWD sources and recruitment potential (Benda et al., 2003). Although the processes of natural wood recruitment have been studied in detail (Martin and Benda, 2002; Benda et al., 2003; May and Gresswell, 2003a), an extrapolation of reach-scale recruitment processes to whole watersheds has not yet been achieved.

Remote sensing technology offers a route to a spatially explicit analysis of potential wood recruitment at the watershed scale. High-resolution light detection and ranging (lidar) has been used to assess a number of forest structure attributes including canopy height and density (Weltz et al., 1994; Magnussen and Boudewyn, 1998; Lefsky et al., 2002), which are indicators of potential wood sources. Concurrently, a high level of topographic detail can help identify dominant LWD sourcing mechanisms (channel migration and hillslope failure). To date, these capabilities have not been used to conduct watershed-scale assessments of potential wood recruitment.

We developed a rapid and spatially extensive geomorphic analysis using lidar data and applied it to the 78-km-long Narraguagus River in coastal Maine, USA. Our objectives were as follows: (i) to estimate tree height and recruitable tree abundance throughout the watershed; (ii) to determine the likelihood for the stream to recruit channel-spanning trees at reach scales and assess whether mass wasting or channel migration is a dominant recruitment mechanism; and (iii) to understand the past and future roles of LWD at a watershed scale. The approach and methods presented herein may aid in the siting of conservation tracts and LWD addition projects, build on previous research that has studied the recruitment and geomorphic role of LWD at the watershed scale (Marcus et al., 2002; Fremier et al., 2010) and validate efforts at modelling wood recruitment to streams (Benda and Sias, 2003).

\section{LANDSCAPE CONTEXT}

Northern New England forests have undergone temporally intense and spatially dramatic changes since the onset of European colonization over three centuries ago (Lorimer, 1977; NRC, 2004). Over 92\% of Maine's land area was forested in 1600 , yet by 1872 only half of that forested area remained as a result of intense timber harvest and land clearing for agriculture. In the last century, following largescale geographic shifts in the forest products industry, farm abandonment following the opening of the Midwest and the more recent introduction of sustainable forest practices and riparian conservation (Maine DEP, 2008), forests have regenerated and now cover $\sim 90 \%$ of the state (NRC, 2004). Yet the present regenerative state of Maine's forests has not translated into a wealth of LWD being found in streams today-current wood loads are among the lowest measured in forested landscapes (Magilligan et al., 2008). Several mechanisms may be responsible for low wood levels, and recovery of pre-disturbance wood levels may lag forest recovery by a century or longer (Bragg, 2000; Laser et al., 2009). In concert with widespread timber harvest, log drives occurred on the Narraguagus River until around 1900 and continued on other coastal Maine streams until around 1970 (Koenig, Steven Koenig, Project SHARE, Eastport, Maine, USA, personal communication), potentially removing any residual wood left in stream channels. In addition to anthropogenic disturbance, it is possible that inherently low site productivity of coastal Maine rivers may place intrinsic limits on the role of wood in these systems. As a result, the inability to confidently detail the past role of LWD in Maine streams leaves managers with neither a baseline value for restoration projects nor a sense of what future role wood might play in the presence of less intensive timber harvest, particularly in riparian zones.

\section{STUDY LOCATION}

The Narraguagus River is located in Washington and Hancock Counties of Maine (Figure 1). It flows south from its headwaters at Eagle Lake and empties directly into the Atlantic Ocean at Milbridge, Maine. The contributing drainage area at the stream's outlet is $588 \mathrm{~km}^{2}$ with a mean channel slope of 0.0015 . The river is one of eight streams, all in coastal Maine, which hold the last remaining wild populations of Atlantic salmon (Salmo salar) in the USA (Maine Department of Marine Resources, 2009). Greatly 


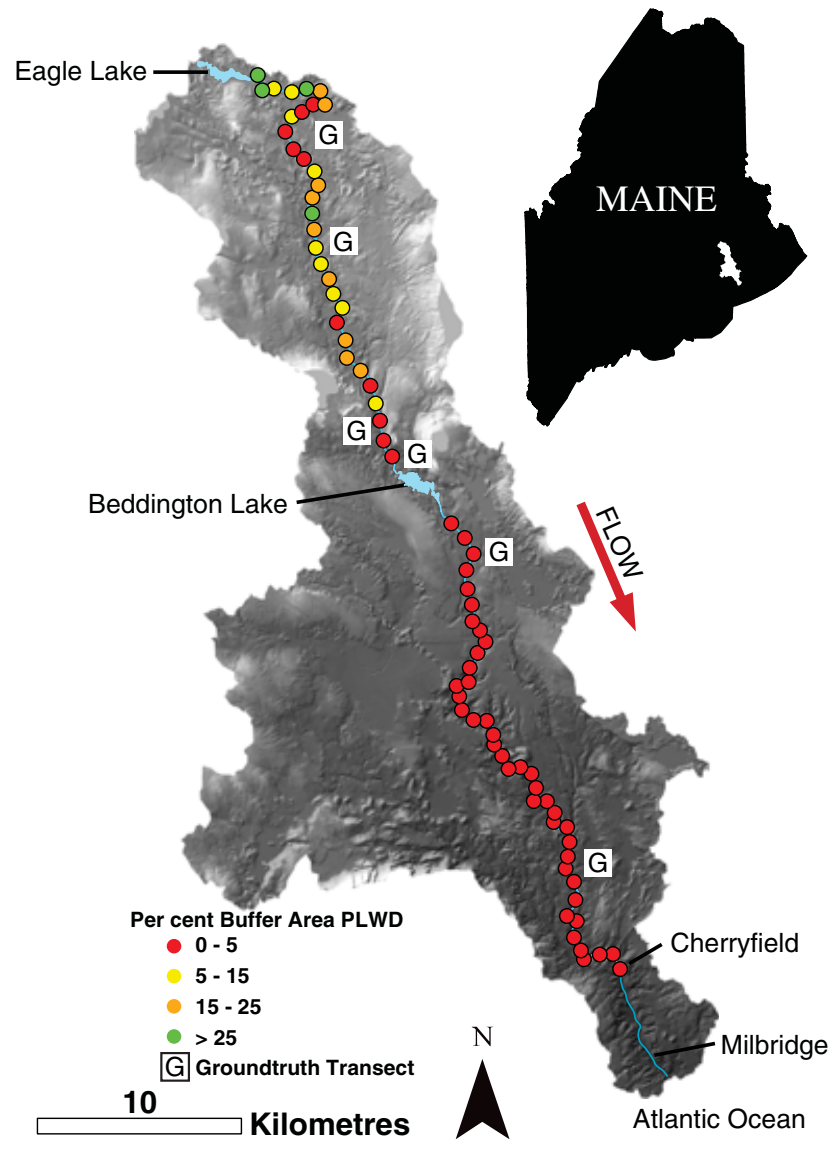

Figure 1. Study area map is a hillshaded US Geological Survey digital elevation model of the Narraguagus River watershed. Narraguagus River is shown in blue. Coloured circles depict the per cent area of valley width composed of channel-spanning pixels. Locations of lidar vegetation height groundtruthing are also shown (two transects were measured at each location). PLWD, potential large woody debris.

reduced from historic levels, the fish are listed under the Endangered Species Act (NRC, 2004). In 2009, a salmon trap in Cherryfield (Figure 1) recorded only eight salmon returning to spawn in the river. The survival of Atlantic salmon is directly tied to the availability of in-channel LWD (Nislow et al., 1999), which leads to the hypothesis that low wood levels in the region may be partially responsible for the low population levels of these fish.

There is only one dam on the river, an approximately 2-m-high crib structure at Cherryfield designed to control ice flow, but its location near the river mouth has minimal impact on basin-scale flow or sediment flux. Other dams, primarily for the temporary storage of water and timber during log drives on the mainstem Narraguagus River, have existed in the past, with the last dam being breached in 1951 (Harriman, 1977). Like many areas of Maine, the Narraguagus basin continues to undergo timber harvest, with roughly $60 \%$ of the watershed under the management of forestry corporations (Arter, 2003). Field observations and aerial photograph examination (USDA, 2007) indicate that the majority of harvesting is presently occurring in the upstream half of the basin. Blueberry farming composes a significant but smaller proportion of present land use and mostly occurs in the downstream half of the basin.

The Narraguagus flows into several mainstem ponds and one large lake (Beddington Lake, $41 \mathrm{~km}$ from the Atlantic Ocean; Figure 1). This lake marks the approximate limit of the late Pleistocene marine transgressive facies (Thompson and Borns, 1985). Upstream of Beddington Lake, the Narraguagus River is primarily underlain by Paleozoic age metasedimentary rocks of the Bucksport and Penobscot formations (Osberg et al., 1985). The river flows over a landscape dominated by glacial till, bounded by relict glacial features such as knobs and eskers (Thompson and Borns, 1985). In this upstream section, bedrock outcrops are common, and the channel bed is generally composed of gravel and cobbles with little sand. Downstream of Beddington Lake, Devonian alkali feldspar granites compose the majority of the bedrock (Osberg et al., 1985), and the stream incises into sands and gravels deposited in a glacial marine outwash delta. In this reach, the channel exhibits a meandering planform and has a finer streambed composed of sand and gravel.

\section{METHODS}

\section{Study segment delineation}

Using ArcGIS (ESRI, Redlands, CA), we divided the Narraguagus River (USFWS, 2006) into 74 study segments, each $1 \mathrm{~km}$ in length (Figure 1). Although the river above the dam in Cherryfield is $78 \mathrm{~km}$ long, kilometres $42-45$ were not considered because of Beddington Lake, which negates the geomorphic effectiveness of LWD in this area. Using 2007 digital orthophotograph quadrangles from the National Agriculture Imagery Program (USDA, 2007), we measured the low-flow channel width (non-flood; defined as the waterfilled channel seen on aerial photographs) every $100 \mathrm{~m}$ along the stream and averaged these measurements to obtain the mean channel width for each 1-km study segment.

\section{Lidar digital elevation model differencing}

Lidar digital elevation models (DEMs) of the Narraguagus River produced via airborne laser swath mapping were collected by the National Center for Airborne Laser Mapping in November 2007. The major advantage of a lidar DEM is its high vertical resolution, which is typically accurate to the decimetre scale (Sallenger et al., 2003; Hodgson and Bresnahan, 2004). Our dataset contained the entire length of the Narraguagus River with 1-m horizontal pixel resolution. We used two lidar grids: the first return 
DEM, which samples elevations of the first object encountered by the laser beam on its path to the ground; and the bare earth DEM, which provides an interpolated elevation model of the ground surface beneath the forest canopy. The TERRASCAN software package (Terrasolid, Helsinki, Finland) was used to filter the lidar point cloud and generate the bare earth DEM. By differencing the first return DEM and the bare earth DEM, we produced a model of vegetation heights (Figure 2). It is important to note that by using raster DEMs, we analysed the vegetation height in individual pixels rather than delineating actual trees throughout the watershed. Lidar has been successfully utilized in the determination of canopy height (Blair et al., 1994; Magnussen and Boudewyn, 1998; Lefsky et al., 2002) and has been validated as an accurate measurement technique for forestry applications (Weltz et al., 1994; Andersen et al., 2006).

\section{Groundtruthing}

We performed field surveys in order to validate the lidarbased vegetation height estimates. Along twelve 50-m bank transects parallel to the Narraguagus River at an average distance of $5 \mathrm{~m}$ from the active channel, we counted and measured trees for height, diameter, species (coniferous or deciduous) and distance along the transect. These transects were intended to be representative of the range of riparian characteristics found along the Narraguagus River and were distributed along the course of the river. Transect locations
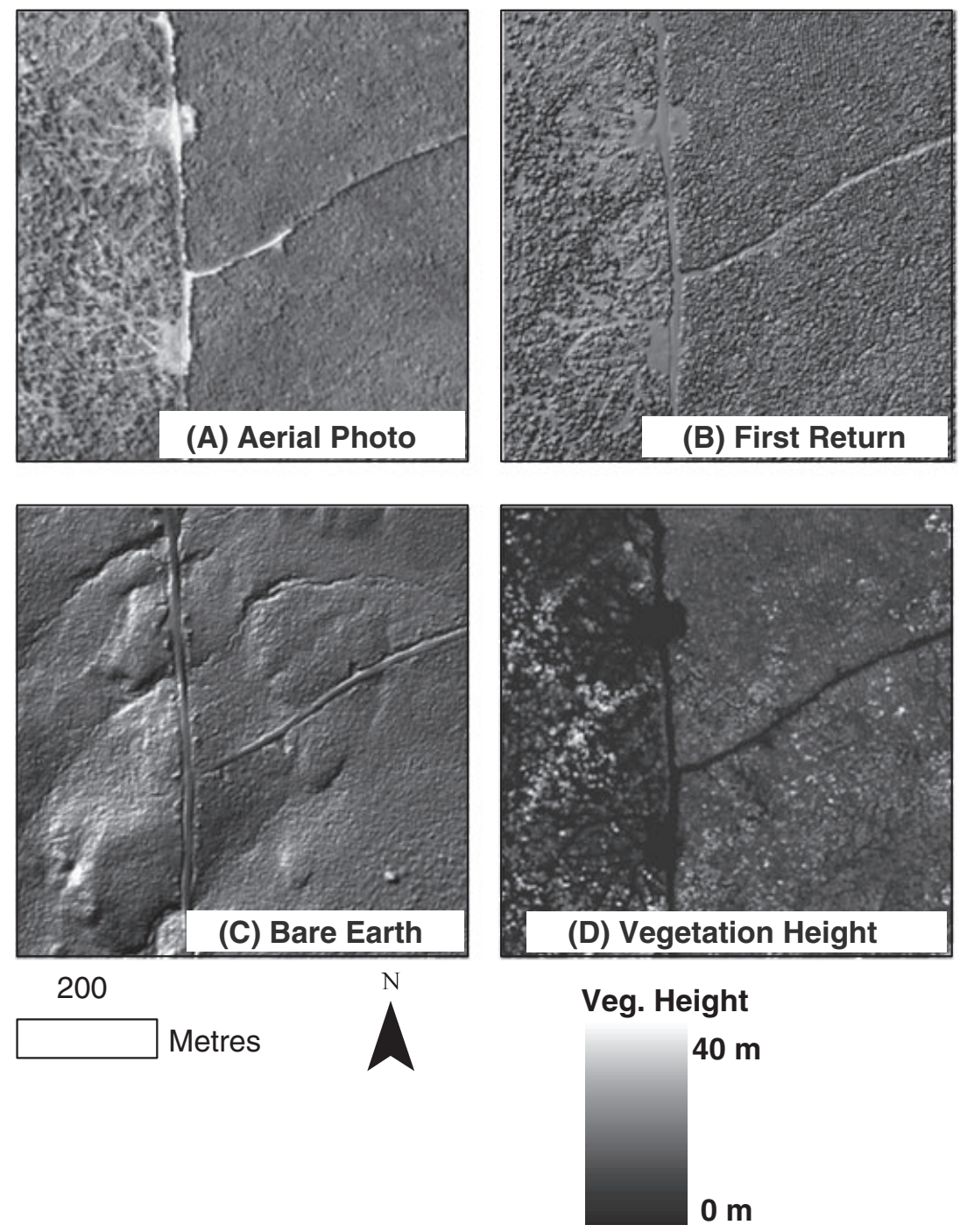

Figure 2. (A) 2007 orthophotograph, (B) hillshaded first-return lidar DEM, (C) hillshaded bare-earth interpolated lidar digital elevation model (DEM) and (D) lidar DEM produced by differencing first-return DEM and bare-earth DEM. All images are of 1-m resolution. Linear features in images are two logging roads. 
are shown in Figure 1; at each location, two transects were measured, one on each bank. We recorded the endpoints of each transect via global positioning system, and the results of this groundtruthing campaign were compared with the number of channel-spanning vegetation pixels observed via lidar analyses along identical transects.

\section{Potential LWD delineation}

In this study, we defined 'potential LWD' (PLWD) as those pixels of the vegetation height DEM that were both channel spanning and potentially recruitable.

Channel spanning means that an individual pixel of the vegetation height DEM had an elevation equal to or exceeding the width of the low-flow stream channel within a particular study segment. Although we acknowledge that LWD of many size ranges influences channel morphology and habitat heterogeneity, we focused on channel-spanning wood as the metric. As a result of piece length, channel-spanning LWD is more likely to be stable (Lienkaemper and Swanson, 1987; Nakamura and Swanson) in high flows and to form integral components of log jams (Montgomery et al., 2003), thereby exerting greater and longer-term geomorphic and habitat influence than smaller pieces. Additionally, we placed an upper bound on the height of PLWD. Given that the tallest trees found in Maine are $\sim 40 \mathrm{~m}$ (Maine Department of Conservation, 2009), any vegetation height values over $40 \mathrm{~m}$ were discarded as erroneously high, likely an artefact of the laser striking an airborne particle during lidar surveying. Approximately $0.004 \%$ of all pixels were discarded.

Potentially recruitable means that a certain pixel of the vegetation height DEM is able to contribute wood to the channel in a particular study segment. Using the bare-earth lidar DEM, we delineated the total valley width (the distance between the tops of the valley walls measured orthogonal to channel flow) and hypothesized that all trees within this area can be recruited to the channel (Figure 3). Such recruitment may occur by a variety of mechanisms including mass wasting (May and Gresswell, 2003a, b), channel migration and bank undercutting (Swanson and Lienkaemper, 1978;
Webb and Erskine, 2003), stochastic mechanisms such as wind throw, fire and avalanches (Hairston-Strang and Adams, 1998; Conrad, 2003; Benda and Sias, 2003) and simple tree mortality (Benda et al., 2003). Because our focus was on the role of geomorphic processes in supplying LWD to the channel, we took a spatially inclusive approach regarding the amount of available PLWD that included valley bottoms and adjacent hillslopes. Although mass wasting is a limited recruitment mechanism in the low-relief watersheds of coastal Maine, we still wanted to include a watershed-scale inventory of potential wood sources, as one of our goals was to develop a method which may be extended to other basins with differing relief structures.

Along 1-km segments of channel length, all vegetation height pixels located in the valley-width area, which were equal to or greater than the mean channel width, were counted as PLWD.

\section{Geomorphic surface delineation}

To more precisely locate sources of PLWD, we used the bare-earth lidar DEM to manually divide the valley into three surface types: active floodplains, terraces and hillslopes (Figure 3). Active floodplains are areas that the channel regularly accesses and are marked by features such as scroll bars and oxbows, generally located about $1 \mathrm{~m}$ above the active channel. Terrace surfaces are generally gently sloping to flatlying and located adjacent to and generally $1-2 \mathrm{~m}$ above the active floodplain. Hillslopes are more steeply inclined areas encompassing the remainder of the valley width. All three surface types were not necessarily present adjacent to every $1-\mathrm{km}$ study segment. We calculated the amount of PLWD in each of these surface types for every study segment.

\section{Spatial overlap between recruitment sources and mechanisms}

To determine reach-scale controls on LWD recruitment, we divided the mainstem valley into reaches, drawing on concepts developed in previous studies (Grant and Swanson, 1995; Bisson et al., 2006). We observed that wide valleys are

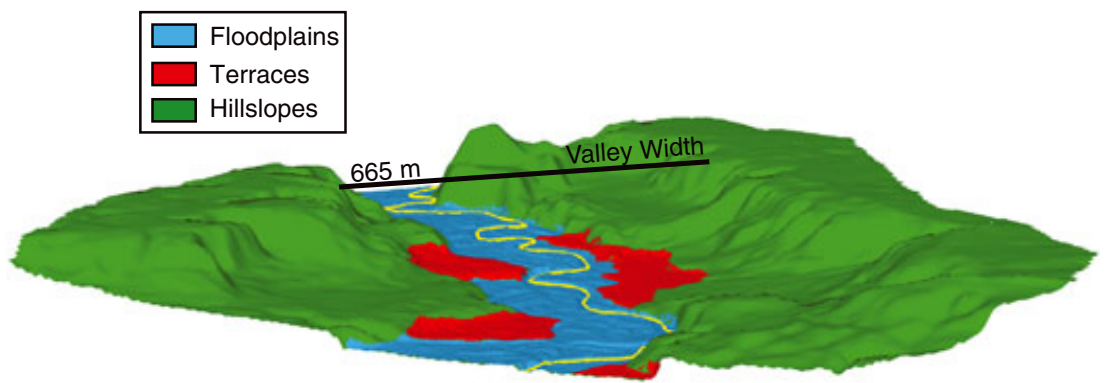

Figure 3. Oblique hillshaded bare-earth lidar digital elevation model showing geomorphic surfaces within Narraguagus River valley (kilometre 26). Vertical exaggeration 3.5x. 
associated with broad floodplains and gradually sloping valley walls, which indicates that channel migration, and not hillslope mass wasting, would be the dominant process of tree recruitment. Conversely, narrow valleys tended to have steeply sloping walls and relatively little floodplain area, which leads us to hypothesize that hillslope wasting would be the dominant recruitment process in such segments. By dividing the range of valley widths into thirds, we classified valley reaches as wide, intermediate or confined (Figure 4). In all, five channel reaches were delineated based on valley width.

We then subdivided the reaches of valley width based on two other variables: channel sinuosity and mean valley-side slope, which we hypothesized to indicate the respective ability of channel migration or mass wasting to recruit wood to the channel. As before, we split the ranges of channel sinuosity and valley-side slope into thirds. We assigned values of sinuous/intermediate/straight for channel sinuosity and steep/ intermediate/flat for valley-side slope. When all three geomorphic variables (valley width, sinuosity and valley-side slope) were considered, 11 channel reaches were delineated (Figures 4 and 9; Table 1). The reaches range in length from 3 to $14 \mathrm{~km}$.

Using the divisions of valley width, sinuosity and valleyside slope, we hypothesized the dominant recruitment process in every stream reach. For all stream reaches, we calculated 'recruitment scores', which attempt to quantify the amount of PLWD recruitment in a particular reach likely to occur as hillslope wasting, as opposed to channel migration. We calculated recruitment scores using the following equation, which provides a ratio of morphologies promoting PLWD recruitment via hillslope mass wasting (steep valley-side slopes and narrow valleys) to those variables which promote recruitment via channel migration (gradually sloping valley sides and sinuous stream channels):

$$
\text { Recruitment score }=\frac{\frac{\text { Valley side slope }}{\text { Valley width }}}{\text { Channel sinuosity }} * 1000
$$

In Equation (1), the ratio of valley slope to valley width provides an estimate of the likelihood for mass wasting to occur, as steep-walled narrow valleys are more prone to landslides. Similarly, the measurement of channel sinuosity quantifies the propensity for lateral migration to recruit PLWD. Thus, high recruitment scores in Equation (1) indicate that hillslope mass wasting is the dominant PLWD recruitment process in the reach, whereas low scores indicate that channel migration is more dominant in PLWD recruitment.

Divisions based on Valley Width:

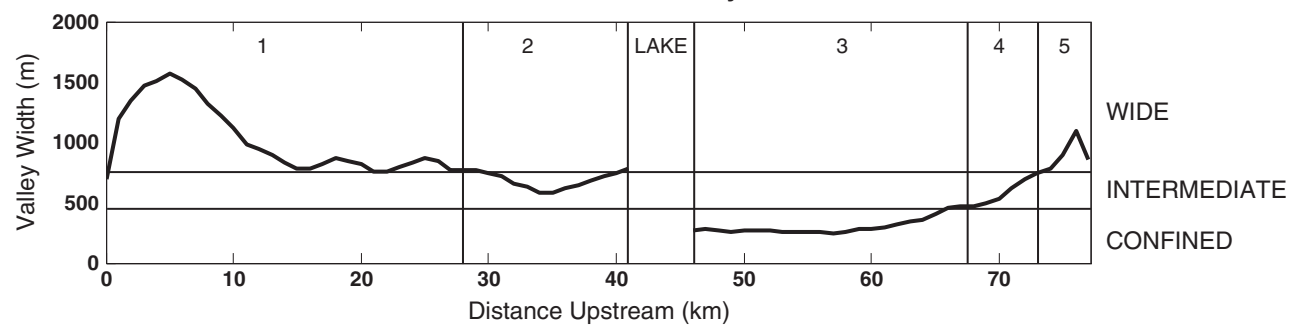

Subdivisions based on Sinuosity and Valley-Side Slope:

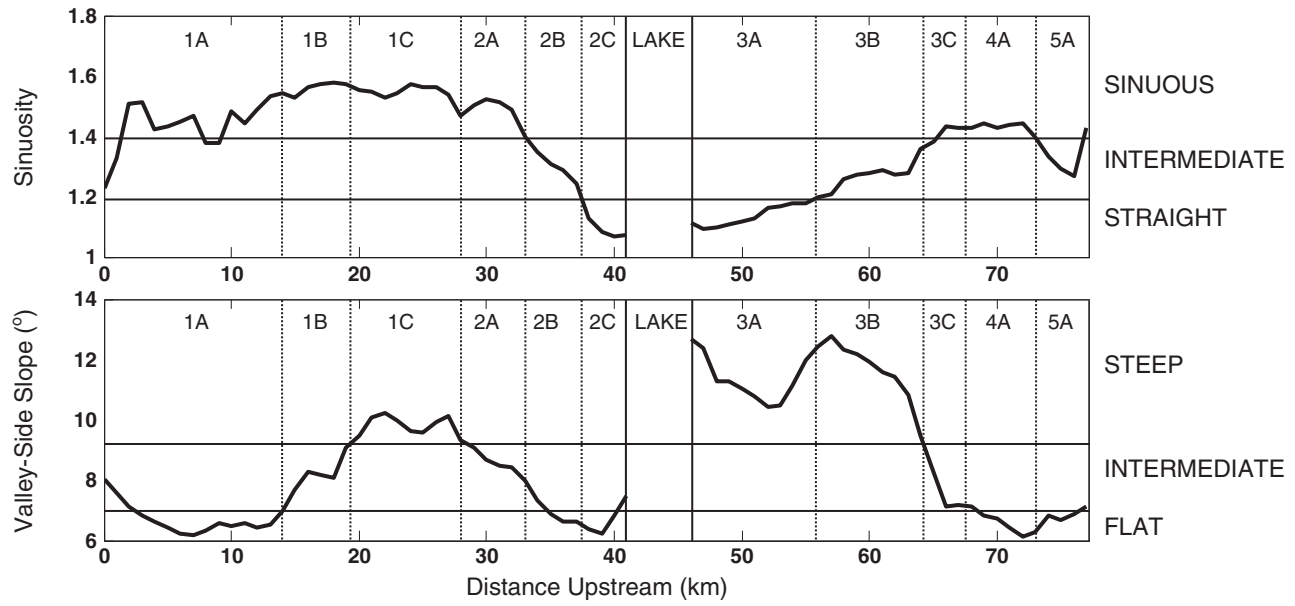

Figure 4. Graphs of stream reach delineations along the Narraguagus River. Values of valley width, sinuosity and mean valley-side slope were averaged every $100 \mathrm{~m}$ to yield a single value for each $1-\mathrm{km}$ study segment. The ranges of values were subsequently divided into thirds.

Reaches were first delineated using valley width and then subdivided on the basis of channel sinuosity and mean valley-side slope. 
Table I. Calculated recruitment scores for all stream reaches

\begin{tabular}{lccllll}
\hline Reach & From km & To km & Valley width & Sinuosity & Valley slope & Recruitment score \\
\hline 1A & 0 & 14 & Wide & Sinuous & Flat & 3.68 \\
1B & 15 & 19 & Wide & Sinuous & Intermediate & 6.27 \\
1C & 20 & 28 & Wide & Sinuous & Steep & 7.38 \\
2A & 29 & 33 & Intermediate & Sinuous & Intermediate & 8.61 \\
2B & 34 & 37 & Intermediate & Intermediate & Intermediate \\
2C & 38 & 41 & Intermediate & Straight & Intermediate & 8.48 \\
3A & 46 & 56 & Confined & Straight & Steep & 35.96 \\
3B & 57 & 64 & Confined & Intermediate & Steep & 32.72 \\
3C & 65 & 68 & Confined & Intermediate & Intermediate & \\
4A & 69 & 74 & Intermediate & Sinuous & Flat & 7.15 \\
5A & 75 & 77 & Wide & Intermediate & Flat & 4.94 \\
\hline
\end{tabular}

Scores were calculated using Equation (1) and represent a ratio of valley morphologies promoting PLWD recruitment via mass wasting to those promoting recruitment by channel migration.

\section{Channel-proximal PLWD delineation}

Although we hypothesized that the channel may recruit wood from the entire valley via migration or hillslope wasting, prior work has shown distance from the channel to be an important factor in wood delivery (McDade et al., 1990). Processes such as wind throw and tree mortality, which can source LWD from areas directly adjacent to streams, can be integral in LWD recruitment (Hairston-Strang and Adams, 1998; Benda et al., 2003; Conrad, 2003). As such, we used lidar to estimate the quantity of PLWD which may be recruited by simply falling into the channel. Using ArcGIS, we delineated all lidar pixels that satisfy this expression:

\section{$($ Vegetation height $)-($ Distance from channel $) \geq$ (Channel width)}

The preceding expression gives an estimate of the trees that, upon falling, could span the adjacent stream channel (hereafter referred to as proximal PLWD). Previous work regarding LWD recruitment via tree fall into streams have illustrated the complexities of such delivery, chiefly fall direction and frequency of tree fall (Hairston-Strang and Adams, 1998; Bragg and Kershner, 2004; Sobota et al., 2006; Teply et al., 2007). Here, our aim was to provide a rapid inventory of potential wood sources at the watershed scale, so we performed a more inclusive analysis of proximal PLWD by assuming a best-case scenario of tree fall directly into the river channel. Research has shown that the majority of tree fall in sites across the Pacific Northwest indeed occurred in a direction towards the stream (Sobota et al., 2006), largely an effect of valley-side slope.

\section{Predicted future conditions}

In order to quantify future LWD recruitment potential, we employed the Upland and Riparian Northeastern Coarse Woody Debris (NE-CWD) model (Lester et al., 2003). The model simulates ecological processes for dominant tree species of New England shown to be representative of stand conditions in the watershed as a whole (Nislow and Lowe, 2006). For our analyses, we used the model component that estimates stand dynamics (ingrowth, diameter growth and mortality) using functions derived from the NE-TWIGS (Northeastern Variant of The Woodsman's Ideal Growth Projection System) model (Hilt and Teck, 1989), an individual-tree stand growth simulator for the northeastern USA. All processes are based on annual time steps, using a Monte Carlo approach, where replicated runs are averaged to obtain output stand attributes (size and density of trees). In the absence of site-specific information regarding initial stand conditions and exact species distributions, we applied uniform growth and mortality parameters in conjunction with published regional forest species compositions (Powell, 1985) across the study area.

As model inputs, we used stand data, including number of trees and tree diameter, collected during lidar groundtruthing along twelve $50 \mathrm{~m}$ by $4 \mathrm{~m}$ bank transects parallel to the Narraguagus River. Combining the data from these transects, we used the diameter of all trees recorded, along with tree species distributions obtained from published forest composition for the region (Powell, 1985) as inputs. We then ran the NE-CWD model and allowed the simulated stand to develop for 100 years. We used the model predictions of diameter growth to estimate tree height using regressions developed from the survey data (Figure 5) and then used these new size and density measures to calculate predicted PLWD along the length of the Narraguagus River.

\section{RESULTS}

\section{Groundtruthing}

The results of field-based groundtruthing, completed in the summer of 2009, are shown in Figure 6. Lidar DEM differencing appears to appropriately estimate vegetation 

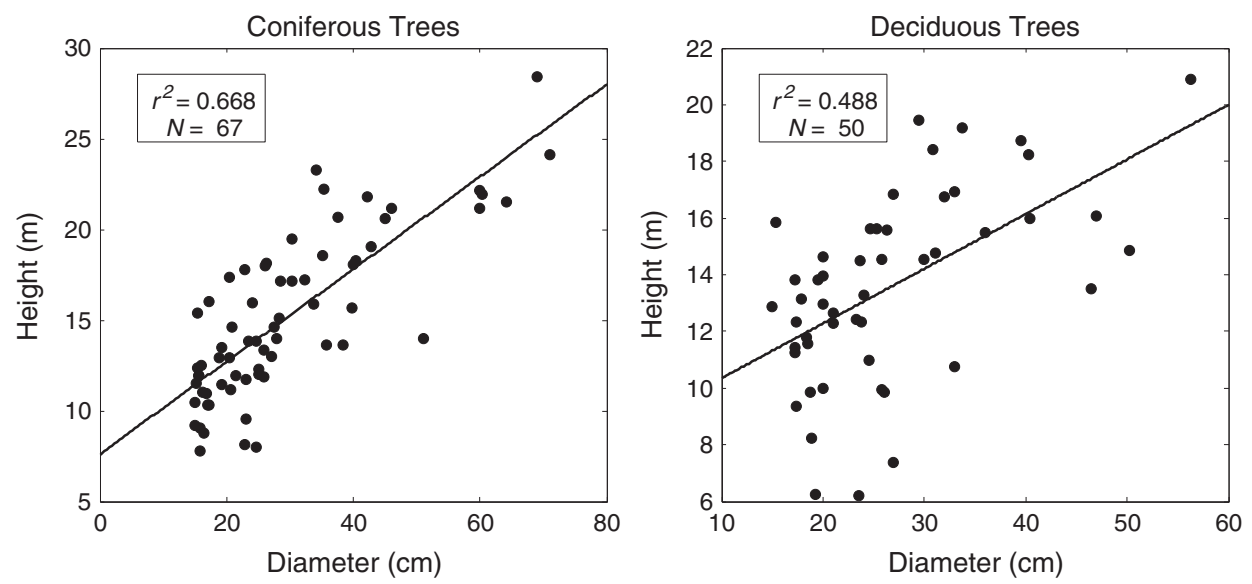

Figure 5. Plots showing correlations between tree diameter and tree height for both coniferous trees (left) and deciduous trees (right).

height $\left(R^{2}=0.89, p<0.001\right)$. Although six of these groundtruth points are located at $(0,0)$, we feel that it is appropriate to include them in the regression because, in this instance, the vegetation height DEM still accurately predicts the lack of trees found at these six sites. Additionally, when these $(0,0)$ points are removed from the regression, the relationship is still statistically significant $(p=0.01)$. Our analysis indicates that one channel-spanning tree crown in the field is, on average, represented by $5.3 \pm 0.38$ channel-spanning pixels on the vegetation height DEM. Figure 6 indicates that the number of channel-spanning pixels derived from the lidar vegetation height DEM is a proxy for the number of channel-spanning trees that are found in a given study segment area. It is important to note, however, that in this study we deal simply with the number of vegetation pixels that are tall enough to span the channel in a particular study segment, and not individual trees.

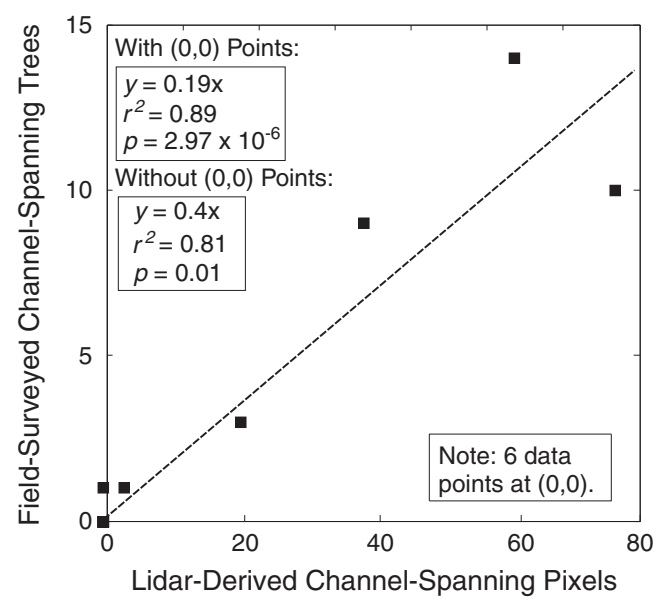

Figure 6. Comparison between number of pixels of lidar-derived potential large woody debris along twelve $4 \mathrm{~m}$ by $50 \mathrm{~m}$ riparian bank transects and actual number of field-surveyed channel-spanning trees.

\section{Longitudinal distribution of PLWD}

The distribution of PLWD along the Narraguagus River is not uniform. Rather, the majority of PLWD is contained within a relatively small number of study segments. For example, more than half of all PLWD is found in the upstream $5 \mathrm{~km}$ of the river [Figures 1 and $7(\mathrm{C})$ ]. Additionally, more than $75 \%$ of PLWD is located within the upper $18 \mathrm{~km}$ of the stream, with the downstream $51 \mathrm{~km}$ of the river accounting for just 10\% of the PLWD in the system [Figure 7(C)]. The total abundance of PLWD is never more than $50 \%$ of the area in any $1-\mathrm{km}$ study segment and is rarely greater than 25\% [Figure 7(B)]. Further, downstream of Beddington Lake (river kilometre 41), essentially no PLWD exists.

The amount of PLWD in a given study segment is largely a function of channel width (Figure 8), as fewer trees within a given river segment are able to span a wide channel as compared with a narrow one. Virtually no PLWD is available where channel width exceeds $\sim 15 \mathrm{~m}$. However, considerable variability exists in the percentage of study segment area composed of PLWD when the channel width is less than $\sim 15 \mathrm{~m}$, which indicates that channel width is not the only control on PLWD availability.

Strong spatial clustering exists in the longitudinal distribution of PLWD. Individual 1-km study segments can have a large influence on the total amount of PLWD found in the entire system. For example, river kilometres 77, 76 and 73 contain $15 \%, 24 \%$ and $10 \%$ of all the PLWD found in the system, respectively [Figures 1 and 7(C)]. These three study segments alone thus account for roughly half of all PLWD available to the Narraguagus River.

\section{Cross-sectional PLWD distribution}

In general, the amount of PLWD located on hillsslopes exceeds that located on floodplains or terraces [Figure 7(E)]. 

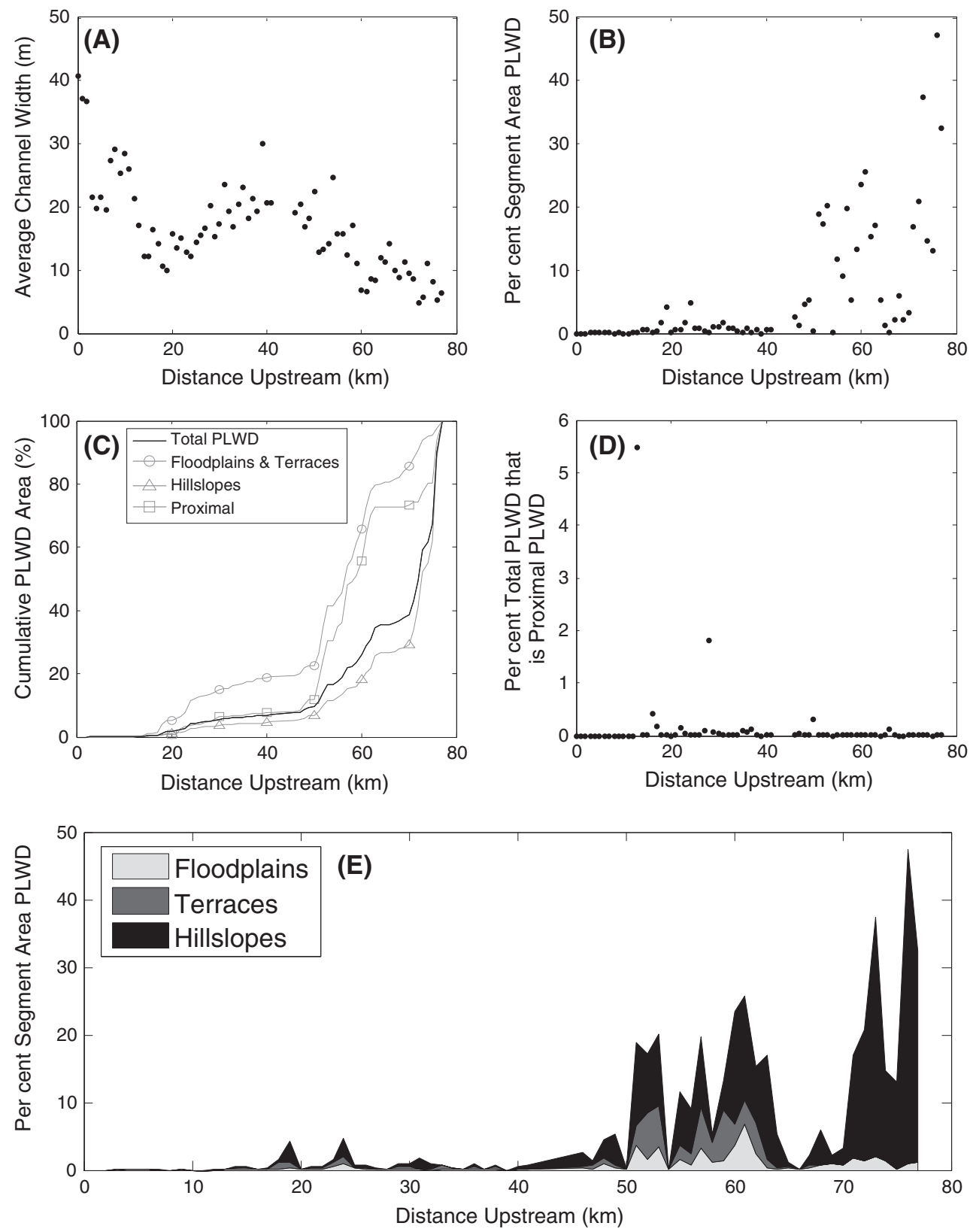

Figure 7. Plotted against increasing upstream distance are the following: (A) average channel width in each 1-km study segment, (B) per cent of area in each 1-km study segment composed of potential large woody debris (PLWD) pixels, (C) cumulative per cent of area in each 1-km study segment composed of PLWD pixels, (D) per cent of all PLWD pixels in 1-km study segments, which are proximal PLWD (able to fall and immediately span the channel) and (E) distribution of PLWD on active floodplain, terrace and hillslope surfaces.

Hillslopes contain $83 \%$ of all PLWD in the system, as compared with $9 \%$ on terraces and $8 \%$ on floodplains. Although hillslope area in the study area is about 4.5 times greater than either floodplain or terrace area, the greater amount of PLWD is not simply an artefact of the areal extent of hillslope surfaces. In terms of volume of wood, hillslopes contain roughly twice as much PLWD per square metre than floodplains and terraces, explaining why the overall longitudinal distribution of PLWD [Figure 7(C)] largely mirrors the distribution on hillslope surfaces. In river kilometres 68 through 77, we indentified no terrace surfaces using the bare-earth lidar DEM, and thus no PLWD exists on terraces in these study segments.

\section{PLWD location versus dominant recruitment mechanisms}

The calculated recruitment scores vary considerably between delineated reaches (Table 1; Figure 9). Eight of 11 


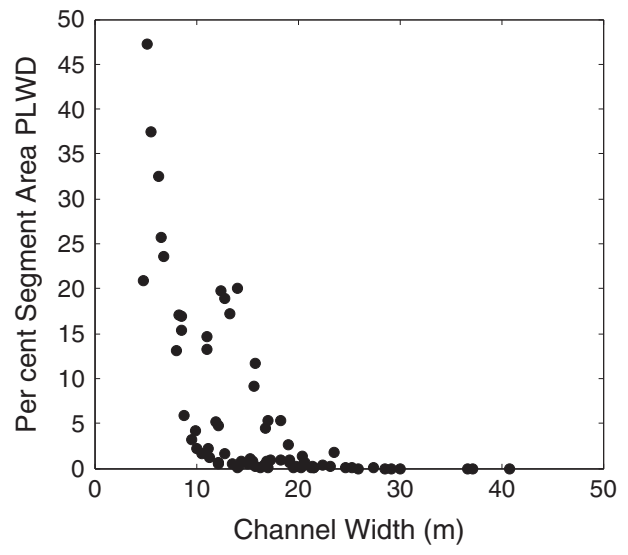

Figure 8. Percentage of area in each 1-km study segment composed of potential large woody debris (PLWD) pixels, with increasing channel width.

reaches (encompassing 68\% of river length) have low scores associated with gradual-to-medium slopes and high channel sinuosity, which indicates that channel migration would be the dominant LWD recruitment mechanism in these locations. However, in these reaches, most of the PWLD is located on hillslopes (Figures 9 and 10), as floodplains and terraces are largely unforested, which indicates a disconnect between dominant recruitment mechanisms and PLWD source locations. In the remaining three reaches (which make up $31 \%$ of river length), dominant recruitment mechanisms are more positively correlated with PLWD sources. Of these, hillslope wasting is predicted to be the dominant recruitment mechanism in two reaches (3A and 3B) where most PLWD was present on hillslopes, and channel migration is predicted to be the dominant mechanism in reach $2 \mathrm{~B}$, where a large proportion of PLWD was available on terrace and floodplain surfaces (Figure 10).

\section{Future LWD supply}

Over a 100-year simulation, with no timber harvest occurring, the results of the NE-CWD model (Table 2) show that the number of proximal trees within the surveyed plot will remain relatively constant (144 surveyed trees in 2009 compared with 149 predicted trees in 2109). However, the mean diameter of trees in the plot increases substantially from $21.8 \mathrm{~cm}$ in 2009 to $54.5 \mathrm{~cm}$ in 2109 . As our field data indicate, tree diameter is related to tree height (Figure 5) for both deciduous and coniferous species. The increase in diameter will correspond to a height increase of approximately $8.8 \mathrm{~m}$ (for conifers) and $8.0 \mathrm{~m}$ (for deciduous trees) in 100 years, which implies that a greater amount of PLWD will be available to the Narraguagus River in the future. The results of this increase in tree height are shown in Figure 11, which implies that the distribution of PLWD along the

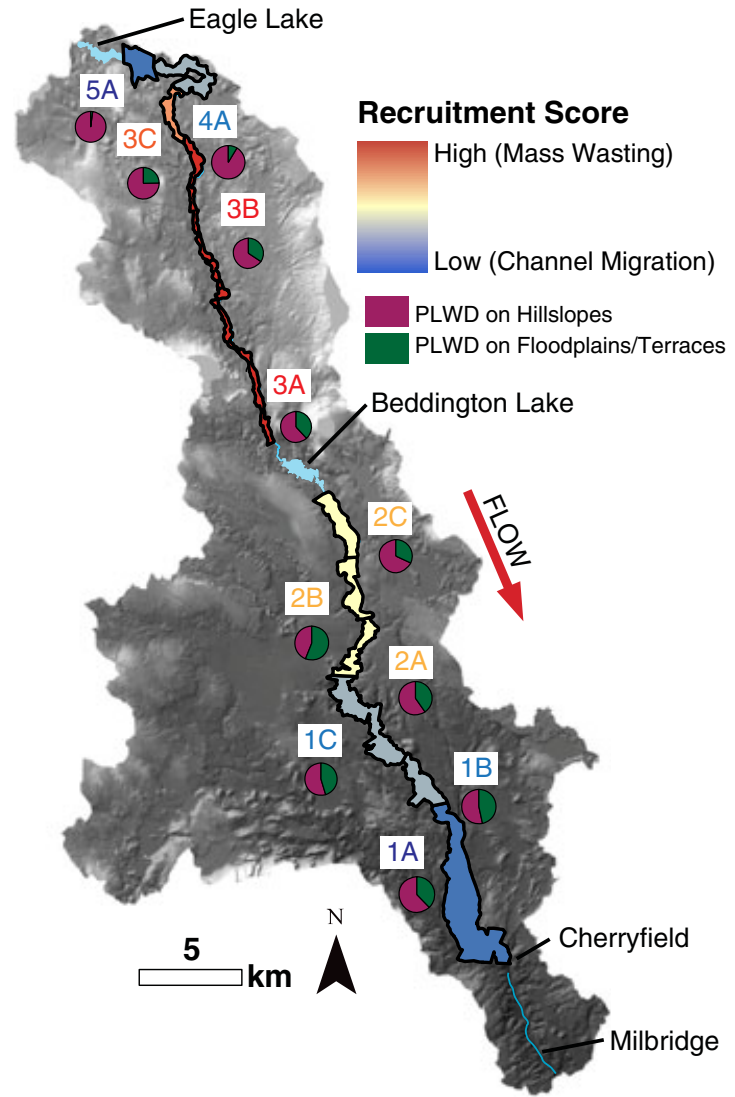

Figure 9. Map of calculated recruitment scores [Equation (1)] for 11 stream reaches along the Narraguagus River (Table 1). High recruitment scores predict that potential large woody debris (PLWD) recruitment will occur via mass wasting, whereas low scores predict recruitment by channel migration. Pie charts show the distribution of PLWD in the valley width for individual reaches. Base is a hillshaded US Geological Survey digital elevation model.

Narraguagus River will be more spatially uniform and that the lower reaches of the stream will have a greater potential to contribute PLWD 100 years into the future-although channel width may still exert a large control on the amount of PLWD available to a particular stream reach.

\section{Proximal PLWD distribution}

Proximal PLWD, defined as those vegetation pixels that may contribute channel-spanning wood simply by falling into the adjacent channel, rarely composes a significant fraction of the total PLWD within a study segment [Figure 7 (D)]. When all PLWD pixels within a 1-km segment are examined, it is rare that more than $1 \%$ of those are proximal PLWD pixels. The two instances where proximal PLWD composes more than $1 \%$ of all PLWD in a study segment occur at river kilometres 13 and 28, where proximal PLWD contributes $5.5 \%$ and $1.8 \%$ of all PLWD, respectively [Figure 7(D)]. However, these numbers should be taken 


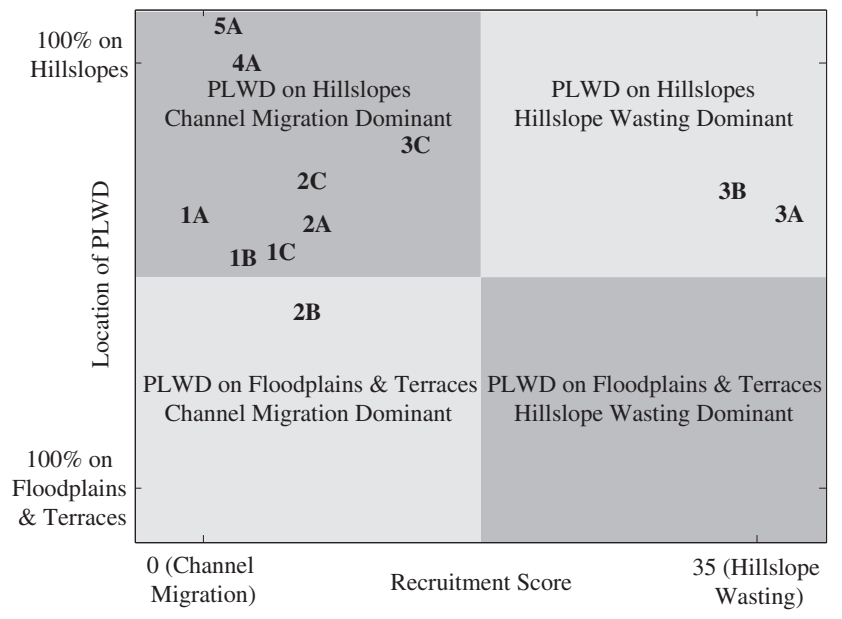

Figure 10. Conceptual model for recruitment propensity within the delineated stream reaches. Percentage of potential large woody debris (PLWD) located on hillslopes versus that on floodplains and terraces is plotted against the recruitment score for every stream reach.

with caution, as those two reaches contain an extremely small amount of total PLWD $(0.04 \%$ and $0.09 \%$ of total recruitment zone area), and thus the proximal PLWD percentages may be skewed by the correspondingly small population size in each of those segments. Although proximal PLWD composes a small fraction of the overall wood available to the Narraguagus River in a particular study segment, LWD recruitment from areas close to the Narraguagus River may rely heavily on this source of channel-spanning wood. Currently, $0.03 \%$ of valley width area along the Narraguagus River is composed of proximal PLWD. Yet predictions of tree growth using the NE-CWD model indicated that, in 100 years, $0.4 \%$ of buffer area will be composed of proximal PLWD, which equates to an 11-fold increase in the amount of proximal PLWD available. When our estimate of one channel-spanning tree being represented by $5.03 \pm 0.38$ channel-spanning lidar pixels is used, this modelled increase in PLWD means that although there are

Table II. NE-CWD model output for 100-year run with no timber harvest, showing number of predicted trees within a given diameter class

\begin{tabular}{lcc}
\hline Diameter $(\mathrm{cm})$ & 2009 field surveyed & 2109 model predicted \\
\hline $0-10$ & 6.0 & 0.0 \\
$11-20$ & 75.0 & 83.0 \\
$21-30$ & 42.0 & 26.0 \\
$31-40$ & 15.0 & 14.0 \\
$41-50$ & 3.0 & 13.0 \\
$50+$ & 3.0 & 13.0 \\
Mean diameter & 21.8 & 54.5 \\
\hline
\end{tabular}

Input data were collected during field surveys in the summer of 2009 and included tree species, diameter and height along twelve $50 \mathrm{~m}$ by $4 \mathrm{~m}$ riparian bank transects parallel to the Narraguagus River.

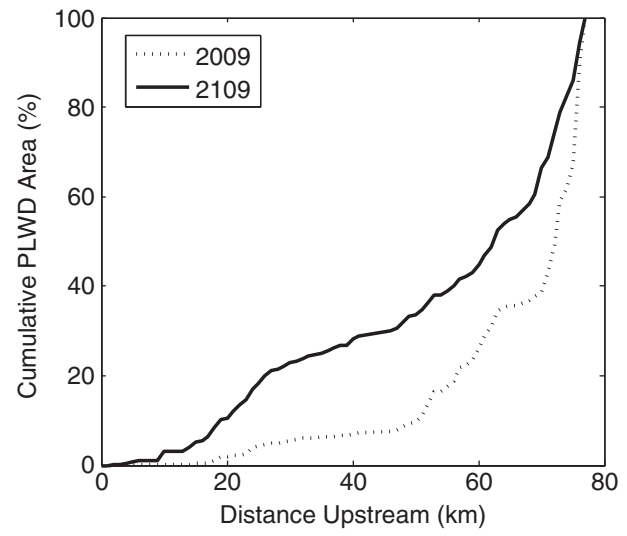

Figure 11. Results of 100-year run of Northeastern Coarse Woody Debris tree growth model; shown are cumulative potential large woody debris (PLWD) distributions along Narraguagus River in 2009 and predicted distribution in 2109.

currently about 2300 proximal channel-spanning trees in our study area, in 100 years' time, this number may increase to around 25500 proximal channel-spanning trees (not accounting for tree mortality or recruitment during this time).

\section{DISCUSSION AND CONCLUSIONS}

We successfully developed a method to use lidar data to evaluate potential wood recruitment at the watershed scale and applied this method to assess spatial and temporal variation in potential wood sources in the Narraguagus River basin of coastal Maine, USA. Lidar data accurately predict the presence of channel-spanning trees along the river and assist in the delineation of valley topography in a way that is directly relevant to potential recruitment of wood. In applying the method to the Narraguagus River, we documented substantial spatial variation in wood sources and recruitment mechanisms. In this basin, a spatial disconnect between valley-wide sources and mechanisms likely restricts recruitment to wood sources immediately adjacent to the river channel and partially explains the very low levels of wood currently observed in this system and potentially in coastal Maine on the whole (Magilligan et al., 2008). However, predicted changes in the size structure of this riparian forest are expected to increase the availability of large wood, which may be retained in wider river sections that are unlikely to be influenced by channel-spanning LWD at present. Whereas sources and mechanisms of wood recruitment vary considerably across regions, our method is easily transferable and may provide a means to understand and explain these regional differences.

One of the most striking findings of the study is the extreme spatial variability in wood sources and recruitment mechanisms along the Narraguagus River. Sources of PLWD 
are disproportionately distributed in the upper $5 \mathrm{~km}$ of the basin. Nearly half of the total PLWD is found in three $1-\mathrm{km}$ study segments ( $<5 \%$ of the total river length). We expect that most river basins will exhibit some spatial variation in wood sources, and longitudinal variability in the amount of wood found in channels (Magilligan et al., 2008; Fisher et al., 2010) may indicate that the spatially discrete distribution of PLWD sources found in this study directly translates to distinct zones of in-channel wood frequency. The finding that the vast majority of wood is located in the upper reaches of the Narraguagus River is also consistent with studies of in-channel wood loads (Wohl and Jaeger, 2008), which found that, overall, wood loading decreased in the downstream direction, likely as a result of the increasing capacity of channels to transport wood in lower reaches.

With particular regard to the Narraguagus River watershed, the character of the New England landscape likely plays a role in the high level of spatial heterogeneity we observed in PLWD distribution. In particular, local-scale $(<10 \mathrm{~km})$ heterogeneity in soil and bedrock characteristics result from glacial activity. Additionally, local-scale variation in land use history (associated with the traditionally small land parcel sizes in this region) will produce high levels of variance in forest characteristics, which in turn will generate variability in the amount of PLWD. This spatial variation has important implications for research and management. At the most immediate level, knowing the location of likely wood sources will help managers prioritize conservation efforts and also help to identify locations that provide a sufficient source of wood for habitat restoration projects. More generally, this high level of spatial heterogeneity underscores the importance of a detailed basin-scale approach. Without a watershed-scale perspective, reliance on 'representative' subsections of forest will yield a highly biased and potentially misleading snapshot of wood sources and recruitment mechanisms.

Our analyses suggest a general model describing a series of spatially nested constraints on wood recruitment to rivers. Moving outward from the river channel, the interaction between channel dimensions, the size structure of the adjacent riparian forest and local-scale recruitment mechanisms (individual tree mortality, wind throw, bank erosion) set a baseline level of wood recruitment from channelproximal trees. Along the Narraguagus River, tree height distributions currently limit the spatial influence of wood to sections less than $\sim 15 \mathrm{~m}$ in width. However, given the protected status of the riparian zone throughout the basin (Maine DEP, 2008), predicted increases in tree size will likely expand this zone of influence. Under these old-growthlike conditions, wood will likely play a greater role in the system, a finding consistent with previous modelling (Nislow, 2010) and empirical work (Keeton et al., 2007) in the northeastern region.
At increasing distance from the channel, wood recruitment at the valley scale depends on the overlap between recruitment sources and dominant recruitment mechanisms. Along the Narraguagus River, PLWD recruitment from beyond the adjacent riparian zone appears unlikely for two reasons. First, although hillslopes along the Narraguagus River represent a large stock of PLWD, these slopes are composed of well-drained upland soils and are generally not steep enough (average valley-side slopes of around $8^{\circ}$ ) to undergo the mass movement that would be necessary to bring that PLWD to the channel. Correspondingly, we observed no evidence of mass wasting (landslide scars and debris piles) during field work on the Narraguagus River. These observations are in strong contrast to studies in the Pacific Northwest (May and Gresswell, 2003a, 2003b), which found that slope instability contributed to in-channel wood loading. Second, although we did observe areas of low-lying floodplains and terraces that could be accessed via channel migration, in this system, these areas provide little recruitable wood, as they are typically large emergent wetlands with little tree cover.

What do these findings mean for the management and future habitat conditions in the Narraguagus River? We argue that the disconnect between distal recruitment sources and mechanisms places an intrinsic limit on the current and future abundance and distribution of wood in the system. Some of these limitations are not amenable to management or restoration. For example, there is little that management can do to establish recruitment from hillslopes when mass wasting is unlikely to occur. Similarly, it is not feasible or desirable to convert natural emergent wetlands to provide a source of wood to the river. These observations suggest that the role and availability of wood is likely to be more limited along the Narraguagus River than in systems where nonproximal recruitment mechanisms are also present. These intrinsic constraints on wood loading can also help to set appropriate management and conservation targets. If the management goal is to restore (as opposed to supplementing or enhancing) a 'natural wood regime' (Laser et al., 2009), a strong focus on forest dynamics in the immediate vicinity of the channel is justified. In systems where appropriate reference conditions are not available, forest vegetation simulation models can then be used to set realistic basin-wide targets for wood recruitment, as well as provide guidelines for active wood restoration projects designed to provide accelerated recovery. This approach was previously used to determine that current wood loads in the streams in the Green Mountains of central New England, USA, were well below predicted old-growth conditions and that current active restoration projects were within the range of these predicted loads (Nislow, 2010).

We acknowledge some important limitations of the lidarbased approach and conceptual model. First, we focus on wood sources and potential recruitment processes and do not 
explicitly incorporate proximal recruitment mechanisms governing tree mortality and fall rates, which can generate considerable variation in actual wood recruitment (Benda et al., 2003). Second, although we concentrate on recruitment of channel-spanning wood, which should be less mobile once in the river (Lienkaemper and Swanson, 1987), wood transport and channel-floodplain exchange, particularly of smaller size fractions, may have an important influence on resultant wood loads. Coupling our approach and conceptual model with more explicit recruitment models would help bridge this gap. Finally, our model is applied only to the mainstem Narraguagus River, and narrower tributary streams may provide more suitable locations for the recruitment of channel-spanning wood. Despite these limitations and simplifications, our approach provides a rapid and spatially inclusive approach to estimate the relative supply of LWD to channels and identifies regions where LWD restoration efforts may be most effective within watersheds.

\section{ACKNOWLEDGEMENTS}

This research was made possible through funding from the Geological Society of America (grant number 9190-09). Lidar data were supported by the National Science Foundation (EAR 0645343), with additional NSF support from grants BCS 0724348 and EAR 0650533. We thank Rohan Chaudhary, Matthew Siegfried and Brynne Weeks (Dartmouth College) for field and laboratory support. Brian Dade, Robert Hawley and Carl Renshaw (Dartmouth College) provided essential insights. Ernie Atkinson, Greg Mackey (MaineDMR) and Jed Wright (USFWS) were instrumental in Maine field support. The manuscript greatly benefited from the comments and suggestions of Carl Legleiter and an anonymous reviewer. This article is dedicated to the memory of Melissa Laser of the Maine Bureau of Sea-Run Fisheries and Habitat.

\section{REFERENCES}

Abbe T, Montgomery D. 1996. Large woody debris jams, channel hydraulics, and habitat formation in large rivers. Regulated Rivers: Research and Management 12: 201-221. DOI: 10.1002/(SICI)10991646(199603)12:2/3<201::AID-RRR390>3.3.CO;2-1

Andersen H, Reutebuch S, McGaughey R. 2006. A rigorous assessment of tree height measurements obtained using airborne lidar and conventional field methods. Canadian Journal of Remote Sensing 32: 355-366.

Arter B. 2003. Narraguagus River watershed nonpoint source pollution management plan. Narraguagus River Watershed Council, Cherryfield, ME.

Assani A, Petit F. 1995. Log-jam effects on bed-load mobility from experiments conducted in a small gravel-bed forest ditch. Catena $\mathbf{2 5}$ : 117-126. DOI: $10.1016 / 0341-8162(95) 00004-\mathrm{C}$

Benda LE, Sias JC. 2003. A quantitative framework for evaluating the mass balance of in-stream organic debris. Forest Ecology and Management 172: 1-16. DOI: $10.1016 / \mathrm{S} 0378-1127(01) 00576-\mathrm{X}$
Benda L, Miller D, Sias J, Martin D, Bilby R, Veldhuisen C, Dunne T. 2003. Wood recruitment processes and wood budgeting. In The Ecology and Management of Wood in World Rivers, Gregory S, Boyer K, Gurnell A (eds). American Fisheries Society: Bethesda; 49-73.

Bernhardt ES, Palmer MA, Allan JD, Alexander G, Barnas K, Brooks S, Carr J, Clayton S, Dahm C, Follstad-Shah J, Galat D, Gloss S, Goodwin P, Hart D, Hassett B, Jenkinson R, Katz S, Kondolf GM, Lake PS, Lave R, Meyer JL, O'Donnel TK, Pagano L, Powell B, Sudduth E. 2005. Synthesizing U.S. river restoration efforts. Science 308: 636-637. DOI: 10.1126/science.1109769

Beschta R. 1979. Debris removal and its effects on sedimentation in an Oregon Coast Range stream. Northwest Science 53: 71-77.

Bilby R. 2003. Decomposition and nutrient dynamics of wood in streams and rivers. In The Ecology and Management of Wood in World Rivers, Gregory SV, Boyer KL, Gurnell M (eds). American Fisheries Society: Bethesda; 135-148.

Bisson P, Montgomery DR, Buffington JM. 2006. Valley segments, stream reaches, and channel units. In Methods in Stream Ecology (Second Edition), Hauer FR, Lamberti GA (eds). Academic Press: San Diego; 23-49. DOI: 10.1016/B978-012332908-0.50004-8

Blair J, Coyle D, Bufton J, Harding D. 1994. Optimization of an airborne laser altimeter for remote sensing of vegetation and tree canopies. Proceedings, IGARSS 1994 2: 939-941.

Bragg D. 2000. Simulating catastrophic and individualistic large woody debris recruitment for a small riparian system. Ecology 81: 1383-1394. DOI: $10.2307 / 177215$

Bragg D, Kershner J. 2004. Sensitivity of a riparian large woody debris recruitment model to the number of contributing banks and tree fall pattern. Western Journal of Applied Forestry 19: 117-122.

Cederholm C, Bilby R, Bisson P, Bumstead T, Fransen B, Scarlett W, Ward J. 1997. Response of juvenile coho salmon and steelhead to placement of large woody debris in a coastal Washington stream. North American Journal of Fisheries Management 17: 947-963. DOI: 10.1577/1548-8675(1997) 017<0947:ROJCSA>2.3.CO;2

Conrad M. 2003. Large woody debris recruitment potential in Aptos Creek Watershed (including Valencia Creek). Technical Report, Coastal Watershed Council, Santa Cruz, CA.

Erskine WD, Webb AA. 2003. Desnagging to resnagging: new directions in river rehabilitation in southeastern Australia. River Research and Applications 19: 233-249. DOI: 10.1002/rra.750

Fausch KD, Northcote T. 1991. Large woody debris and salmonid habitat in a small coastal British Columbia stream. Canadian Journal of Fish and Aquatic Science 49: 682-693. DOI: 10.1139/f92-077

Fisher GB, Magilligan FJ, Kaste JM, Nislow KH. 2010. Constraining the timescales of sediment sequestration associated with large woody debris using cosmogenic ${ }^{7}$ Be. Journal of Geophysical Research 115: F01013. DOI: $10.1029 / 2009$ JF001352

Floyd TA, MacInnis C, Taylor BR. 2009. Effects of artificial wood structures on Atlantic salmon habitat populations in a Nova Scotia stream. River Research and Applications 25: 272-282. DOI: 10.1002/rra.1154

Fremier A, Seo J, Nakamura F. 2010. Watershed controls on the export of large wood from stream corridors. Geomorphology 117: 33-43. DOI: 10.1016/j.geomorph.2009.11.003

Grant G, Swanson F. 1995. Morphology and processes of valley floors in mountain streams, western Cascades, Oregon. In Natural and Anthropogenic Influences in Fluvial Geomorphology: The Wolman Volume, Costa JE, Miller AJ, Potter KW, Wilcock PR (eds). American Geophysical Union: Washington, DC; 83-101.

Gregory SV, Boyer KL, Gurnell AM. 2003. The ecology and management of wood in world rivers. American Fisheries Society, Symposium 37, Bethesda, Maryland.

Gurnell AM, Piégay H, Swanson FJ, Gregory SV. 2002. Large wood and fluvial processes. Freshwater Biology 47: 601-619. DOI: 10.1046/ j.1365-2427.2002.00916.x 
Hairston-Strang A, Adams P. 1998. Potential large woody debris sources in riparian buffers after harvesting in Oregon, USA. Forest Ecology and Management 112: 67-77. DOI: 10.1016/S0378-1127(98)00311-9

Harriman P. 1977. Mills of the Narraguagus. Narraguagus Historical Society: Cherryfield.

Hilt DE, Teck RM. 1989. NE-TWIGS: an individual tree growth and yield projection system for the northeastern United States. The Compiler 7: $10-16$.

Hodgson ME, Bresnahan P. 2004. Accuracy of airborne lidar-derived elevation: empirical assessment and error budget. Photogrammetric Engineering and Remote Sensing 70: 331-339.

Johnson EA. 2009. Hydraulic and geomorphic effects of large woody debris additions in the Narraguagus River Watershed, coastal Maine. Master's thesis, Boston College.

Keeton WS, Kraft CE, Warren DR. 2007. Mature and old-growth riparian forests: structure, dynamics, and effects on Adirondack stream habitats. Ecological Applications 17: 852-868.

Kondolf GM. 1995. Five elements for effective evaluation of stream restoration. Restoration Ecology 3: 133-136. DOI: 10.1111/j.1526-100X. 1995.tb00086.x

Laser M, Jordan J, Nislow KH. 2009. Riparian forest and instream large wood characteristics, West Branch Sheepscot River, Maine, USA. Forest Ecology and Management 257: 1558-1565. DOI: 10.1016/j.foreco.2008.12.024

Lefsky MA, Cohen WB, Parker GG, Harding DJ. 2002. Lidar remote sensing for ecosystem studies. Bioscience 52: 19-30. DOI: 10.1641/ 0006-3568(2002)052[0019:LRSFES]2.0.CO;2

Lester AM, Beatty ID, Nislow KH. 2003. Upland and riparian northeastern coarse woody debris (NE-CWD) model. University of Massachusetts, Amherst.

Lienkaemper GW, Swanson FJ. 1987. Dynamics of large woody debris in streams in old-growth Douglas fir forests. Canadian Journal of Forest Research 2: 150-156. DOI: 10.1139/x87-027

Lorimer CG. 1977. The presettlement forest and natural disturbance cycle of northeastern Maine. Ecology 58: 139-148. DOI: 10.2307/1935115

Magilligan FJ, Nislow KH, Fischer GB, Wright J, Mackey G, Laser M. 2008. The geomorphic function and characteristics of large woody debris in low gradient rivers, Coastal Maine, USA. Geomorphology 97: 467-482. DOI: 10.1016/j.geomorph.2007.08.016

Magnussen S, Boudewyn P. 1998. Derivations of stand heights from airborne laser scanner data with canopy-based quantile estimators. Canadian Journal of Forest Research 28: 1016-1031. DOI: 10.1139/cjfr-28-7-1016

Maine Department of Conservation. 2009. Maine register of big trees. http://www.maine.gov/doc/mfs/projectcanopy/pages/resource/pubs/pdfs/ bigtrees_2009.pdf [accessed on 9 April 2010].

Maine Department of Environmental Protection. 2008. Maine shoreland zoning: a handbook for shoreland owners. http://www.maine.gov/dep/ blwq/docstand/sz/citizenguide.pdf [accessed on 1 April 2010].

Maine Department of Marine Resources. 2009. Salmon trap count statistics. http://www.maine.gov/asc/research/trap_count_stats.shtml [accessed on 9 April 2010].

Marcus WA, Marston RA, Covard CR, Gray RD. 2002. Mapping the spatial and temporal distribution of wood in streams of the greater Yellowstone ecosystem, USA. Geomorphology 44: 323-335. DOI: 10.1016/S0169-555X(01)00181-7

Martin DJ, Benda LE. 2002. Patterns of in-stream wood recruitment and transport at the watershed scale. Transactions of the American Fisheries Society 130: 940-958.

May CL, Gresswell RE. 2003a. Large wood recruitment and redistribution in headwater streams in the southern Oregon Coast Range, USA. Canadian Journal of Forest Research 11: 1352-1362. DOI: 10.1139/x03-023

May CL, Gresswell RE. 2003b. Processes and rates of sediment and wood accumulation in headwaters streams of the Oregon Coast Range, USA. Earth Surface Processes and Landforms 28: 409-424. DOI: 10.1002/esp.450
McDade M, Swanson FJ, McKee Wa, Franklin JF, Van Sickle J. 1990. Source distances for coarse woody debris entering small streams in western Oregon and Washington. Canadian Journal of Forest Research 20: 326-330. DOI: 10.1139/x90-047

Montgomery DR, Buffington JR, Smith RD, Schmidt KM, Pess G. 1995. Pool spacing in forest channels. Water Resources Research 31: 1097-1105. DOI: 10.1029/94WR03285

Montgomery DR, Collins BD, Buffington JM, Abbe TB. 2003. Geomorphic effects of wood in rivers. In The Ecology and Management of Wood in World Rivers, Gregory SV, Boyer KL, Gurnell AM (eds.). American Fisheries Society Symposium 37: 21-47.

National Research Council (NRC), Committee on Atlantic Salmon in Maine. 2004. Atlantic Salmon in Maine. The National Academies Press: Washington, DC.

Nislow KH, Folt CL, Parrish DL. 1999. Favorable foraging locations for young Atlantic Salmon: applications to habitat and population restoration. Ecological Applications 9: 1085-1099. DOI: 10.1890/ 1051-0761(1999)009[1085:FFLFYA]2.0.CO;2

Nislow KH, Lowe WH. 2006. Influences of logging history and riparian forest characteristics on macroinvertebrates and brook trout (Salvelinus fontinalis) in headwater streams (New Hampshire, U.S.A.). Freshwater Biology 51: 388-397. DOI: 10.1111/j.1365-2427.2005.01492.x

Nislow KH. 2010. Riparian management: alternative paradigms and implications for wild salmon. In Salmonid Fisheries: Freshwater Habitat Management, Kemp P (ed.). Wiley-Blackwell: Chichester; 164-182.

Osberg PH, Hussey AM, Boone GM. 1985. Bedrock Geologic Map of Maine. Maine Geological Survey: Augusta.

Powell DS. 1985. Forest composition of Maine: an analysis using number of trees. Resource bulletin NE-85. US Department of Agriculture Forest Service.

Sallenger AH, Krabill WB, Swift RN, Brock J, List J, Hansen M, Holman RA, Manizade S, Sontag J, Meredith A, Morgan K, Yunkel JK, Frederick EB, Stockdon H. 2003. Evaluation of airborne topographic lidar for quantifying beach changes. Journal of Coastal Research 19: 125-133.

Seo JI, Nakamura F, Chun KW. 2010. Dynamics of large wood at the watershed scale: a perspective on current research limits and future directions. Landscape Ecology and Engineering 6: 271-287. DOI: 10.1007/s11355-010-0106-3

Snyder NP, Castele MR, Wright JR. 2009. Bedload entrainment in lowgradient paraglacial coastal rivers of Maine, USA: implications for habitat restoration. Geomorphology 103: 430-446. DOI: 10.1016/j.geomorph.2008.07.013

Sobota D, Gregory S, Sickle JV. 2006. Riparian tree fall directionality and modeling large wood recruitment to streams. Canadian Journal of Forest Research 36: 1243-1254. DOI: 10.1139/X06-022

Sundbaum K, Näslund I. 1997. Effects of woody debris on the growth and behaviour of brown trout in experimental stream channels. Canadian Journal of Zoology 76: 56-61. DOI: 10.1139/cjz-76-1-56

Swanson FJ, Lienkaemper G. 1978. Physical consequences of large organic debris in Pacific Northwest streams. US Forest Service Technical Report PNW-GTR-069.

Teply M, McGreer D, Schult D, Seymour P. 2007. Simulating the effects of forest management of large woody debris in streams in northern Idaho. Western Journal of Applied Forestry 22: 81-87.

Thompson DM. 1995. The effects of large organic debris on sediment processes and stream morphology in Vermont. Geomorphology 11: 235-244. DOI: 10.1016/0169-555X(94)00064-X

Thompson WB, Borns HJ. 1985. Surficial Geologic Map of Maine. Maine Geological Survey: Augusta.

United States Department of Agriculture (USDA). 2007. National agricultural imagery program. http://seamless.usgs.gov [accessed 1 April 2009].

United States Fish and Wildlife Service (USFWS). 2006. Maine Atlantic Salmon habitat survey (GIS shapefile; ashab3). http://megis.maine.gov [accessed 1 April 2009]. 
Webb AA, Erskine WD. 2003. Distribution, recruitment, and geomorphic significance of large woody debris in an alluvial forest stream: Tonghi Creek, southeastern Australia. Geomorphology 51: 109-126. DOI: 10.1016/S0169-555X(02)00327-6

Weltz M, Ritchie J, Fox H. 1994. Comparison of laser and fieldmeasurements of vegetation height and canopy cover. Water Resources Research 30: 1311-1319. DOI: 10.1029/93WR03067

Wilkins BC, Snyder NP. 2010. Geomorphic comparison of two Atlantic coastal rivers: toward an understanding of physical controls on Atlantic salmon habitat. River Research and Applications. 27: 135-156. DOI: 10.1002/rra.1343
Wohl E, Angermeier PL, Bledsoe B, Kondolf GM, MacDonnell L, Merritts DM, Palmer MA, Poff NL, Tarboton D. 1995. River restoration. Water Resources Research 41: 1-12. DOI: 10.1029/2005WR003985

Wohl E, Jaeger K. 2008. A conceptual model for the longitudinal distribution of wood in mountain streams. Earth Surface Processes and Landforms 34: 329-344. DOI: 10.1002/esp.1722

Wohl E, Polvi LE, Cadol D. 2010. Wood distribution along streams draining old-growth floodplain forests in Congaree National Park, South Carolina, USA. Geomorphology 126: 108-120. DOI: 10.1016/ j.geomorph.2010.10.035 